\title{
中山間地域における買い物弱者の現状と対策
}

\author{
武田 彬奈（岡山大学大学院環境学研究科） \\ 小松 泰信（岡山大学） \\ 横溝功 (岡山大学)
}

\section{The Situation of and Problems Faced by People with the Disadvantage of Shopping in Hilly and Mountainous Areas}

\author{
Akina Taketa (Graduate School of Environmental Science,Okayama University) \\ Yasunobu Komatsu (Okayama University) \\ Isao Yokomizo (Okayama University)
}

Recently, a growing number of people have difficulty with daily shopping.

As the purchase of perishable food is difficult for people with shopping disadvantages, their health risks are increasing. The deterioration of living conditions in farm villages, where the primary industry is major, might weaken the autonomy function, lead to population outflow, and consequently, influence the productive activity. Therefore, shopping support is necessary for them.

This report aims to understand the situation of

\section{1. 課題と方法}

平成 20 年度に行われた，「人口減少・高齢化の進 んだ集落等を対象とした『日常生活に関するアン ケート調査』(国土交通省)」内の「生活上で最も困っ ていること」の項目では, 医療関係の不安に次いで, 「近くで食料や日用品を買えないこと」があげられ ている．このような状況の消費者は，「買い物弱者」 と呼ばれ，近年問題視されている.

なかでも農業従事者は生活と生産の場を同じくし て扣り，その生産活動に影響を及ぼすため，早急な 対策が必要である。

本報告では，農村部の多くを占める中山間地域の 買い物弱者の現状を把握し，その支援の展開方向を 考察することを目的とする.

買い物弱者の現状把握については，岡山県内でも 高齢化, 人口減少の著しい高梁市を調査のフィール people with the disadvantage of shopping in hilly and mountainous areas, where many of the farm villages are located, and to consider the opportune direction for developing shopping support.

The objects of the investigation are the city office and small-scale wholesale market in Takahashi City, Okayama Prefecture, where the aging of and decrease in population is remarkable; the business of individual delivering of Okayama Copland JA Hiroshima City.

ドとし, 市役所, 高梁食品総合卸売市場（その他卸 売市場）に扎いてヒアリング調査を行った．買い物 弱者支援の展開方向を考察するに当たっては，沶か やまコープの個別宅配事業，JA広島市のヤマザキ ショップとの提携について調査を行った.

\section{2. 買い物弱者の現状}

\section{（1）買い物弱者の発生}

豊富な品揃えでワンストップ・ショッピングを可 能とする利便性，セルフサービス方式を採用し，低 マージンを実現した低価格販売が評価され，現在多 くの消費者にとっての「買い物の場」は，大規模小 売店，すなわちスーパーマーケットが主流となって いる.

$$
\text { セルフサービス型のスーパーマーケットは } 1950
$$
年代から登場したが，既存の小規模小売店は競合に 
おいて不利な立場にあり，結果，多くの小規模小売 店が閉鎖した。

大規模小売店についても，不況の影響や過剩店舗 なぞが原因で店舗閉鎖の括それがある. 小規模小売 店の減少が進んだ地域で大規模小売店が撤退すれ ば，消費者は買い物の場を失う。

また，中山間地域では，買い物の場となる店舗が 消費者の居住地から遠く離孔ている場合が少なくな い. 大規模小売店は商圏人口を確保するために，人 口集積地帯や交通量の多い道路, バイパス付近を選 んで出店していることが原因である.

自由に運転できる自家用車を保有する場合は，重 い荷物を運ぶ負担が少なく, 消費者のライフスタイ ルに合わせた買い物が可能である。しかし, 経済的 負担や高齢化による運転技術の低下などを理由に徒 歩, 自転車, 公共交通機関を用いる消費者は, 一度 の買い物量や時間に大きな制約を受ける. 加えて, 中山間地域には十分に整備されていない道路も多 く, 事故のリスクや体力的負担が増加している. 公 共交通機関の利用については，毎回の運顀を負担し なくてはならない，加えて利用者の減少による廃線 が増えて打り, 今後も交通事情の悪化が原因の買い 物弱者は増加すると考兄られる。

\section{（2）買い物弱者への影響}

買い物弱者への影響としては, (1)健康リスクの増 大 : 生鮮食品を日常的に購入できず, 栄養が偏る, (2)人口流出 : 生活インフラを欠いた地域では人口流 出が起こり, 残存小売店の商圏居住人口を減らす悪 循環となる, (3)地域自治機能の低下: 地域の環境美 化活動や伝統行事など，体力のある若者世代が担っ てきた役割を高齢者が代わって行らことは困難であ り, 地域自治機能が低下寸る, (4)農業への影響 : 生 活の場と生産の場を同じくする農村部での生活環境 の悪化は, 農作業への悪影響, 農業就業人口の低下 を招く，の4 点があげられる.

中山間地域では過疎化，高齢化ともに進行して抒 り，買い物弱者への負担，影響ともに深刻であるた め, 早急な対策が必要である.

\section{（3）買い物弱者支援の方向性}

「地域インフラを支える流通のあり方研究会報告 書（経済産業省）」では，買い物弱者支援の方向性 として表 194 点をあげている.

これらのサービスは，一部地域で実践されている ものの，採算性の低さを克服することは容易ではな く，普及に至っていない.

\section{表 1. 買い物弱者支援システムとなりえる業態}

\begin{tabular}{|c|c|c|}
\hline 支援方法 & 支援内容 & 課題 \\
\hline (1)宅配サービス & $\begin{array}{l}\text { ・インターネット, 電話, 店頭で注文した商 } \\
\text { 品を顧客宅へ配達 } \\
\text { ・ドア・ツー・ドアによる消費者の移動コス } \\
\quad \text { ト削減 } \\
\text { ・安否確認などを同時に行う } \\
\text { ・小売店の商品取り扱い, 宅配業者の配達ノ } \\
\text { ウハウを活用 }\end{array}$ & $\begin{array}{l}\text { ・高齢者は機械操作が困難 } \\
\text { ・宅配対応エリアと所要時間のトレードオフ } \\
\text { ・コストを価格に転嫁しにくい }\end{array}$ \\
\hline (2)移動販売 & $\begin{array}{l}\text { ・商品を積載した店舗ごと顧客まで移動 } \\
\text { ・消費者自身が商品を選択 } \\
\text { ・消費者同士や事業者とのコミュニケーショ } \\
\text { ンをとる, 福祉サロン機能を有する }\end{array}$ & $\begin{array}{l}\text { ・商圏居住人口減少の中での採算性の確保 } \\
\text { ・販売コストの軽減策 }\end{array}$ \\
\hline (3)店への移動手段の提供 & $\begin{array}{l}\text { ・公共交通機関への補助金 } \\
\text { ・コミュニティバス, 乗合タクシーの導入 } \\
\text { ・電動スクーターの貸し出し }\end{array}$ & $\begin{array}{l}\text { ・利便性の向上による利用者の増加 } \\
\text { ・事業開始手続きの煩雑さの解消 }\end{array}$ \\
\hline (4)便利な店舗立地 & $\begin{array}{l}\text { ・コンビ二の店舗展開 } \\
\text { ・ヤマザキによる多様な店舗形態 } \\
\text { ・住民の共同出資による出店 }\end{array}$ & $\begin{array}{l}\text { ・商圈居住人口減少への対応 } \\
\text { ・多様な収益源の確保（地域の実情把握） } \\
\text { ・利用者の積極的な関与 }\end{array}$ \\
\hline
\end{tabular}

資料：「地域生活インフラを支える流通のあり方研究会報告書」より筆者作成 


\section{3. 岡山県高梁市の事例}

\section{（1）行政の姿勢}

高梁市は, 岡山県中西部に位置し, 地形の汪とん ぞが丘陵部からなる中山間地域である.

人口 38,799 人, らち 65 歳以上の老齢人口は 12,863 人（平成 17 年度国勢調查）である。高齢化率は $33.4 \%$ と岡山県内で 8 位（平成 21 年度）と高い水 準にある. 高齢化率 40\%を超える集落が法とんど であり，60\%を超光る集落も存在する.1995（平成 7）年には-2.1\%であった人口減少率が，2005（平 成 17）年には $-5.5 \%$ まで増大しており，人口流出 も著しい。

現在, 高梁市では主に高齢者を対象とした公共交 通の充実による外出支援を行っている.

まず，路線バスの利便性向上のために，4条路線 バス利用者のらち高梁地区打よび有漢地区に住所を 有する 75 歳以上の人を対象に, 居住地の最寄りの バス停から高梁バスセンター(有漢地域は郷バス停) までの片道バス料金相当額を,「バス拉よびタクシー 利用券」として交付している.

この利用券配布の対象外の地域については, 生活 福祉バスの増便によって対応している.

これらに加光, バス停, タクシー営業所から離れ た「公共交通空白地带」の減少を目指し，乗合タク シ一の運行を一部地域で開始している.

他にも，市は事業委託料や車両維持費など，2008 （平成 20 年）度には 2 億 1 千万円を負担している. 今後も事業者の採算性を考慮した持続可能な取り組 又を目指している。

\section{（2）小売店, 卸売市場の姿勢}

高梁市で高梁食品総合卸売市場の担ら役割は大き い. 当該卸売市場は, 高梁市中心部に位置する小規 模卸売市場, 「その他卸売市場」である. 高梁市の 人口減少による需要の低迷が経営に影響している が, 生鮮食品, 調味料, 加工品, 業務用農産物など 多種多様な品目を取り扱い, 幅広いニーズへの対応 で経営の安定化を図っている.

取引先は, 地域の小売店や医療施設, 商業施設な ぞであり，市民の生活環境の維持に貢献している. 大規模卸売市場には無い, その他卸売市場ならでは のきめ細やかな配送業務が高梁市の流通を支えてい るといえる.

しかし, 小売店経営者の高齢化と後継者不足が深
刻化している，設備の更新などをきっかけに廃業を 選択するケースは少なくない，小売店の廃業は，高 梁市の食料品供給システムに支障をきたすため，歯 止めとなる対策が必要である.

\section{（3）消費者のニーズ}

高梁市内でもとくに人口減少，高齢化の著しい玉 川地域と平川地区では，2008（平成 20）年度から, 集落活性化計画が進められている，計画の策定に当 たって, 複数回にわたる住民座談会および住民アン ケートを実施し地域の実態を把握した.

買い物に不便を感じる住人が最も多く，他にも医 療や教育についての不安を抱兄ている。しかしなが ら，座談会では地域の伝統芸能や文化に誇りを感じ るとの意見が多く聞かれ，アンケートからは住み慣 れた土地に暮らし続けたいと考える住民がほとんど であることがわかった。

これを踏まえ協議会は, 住民の買い物行動に関し て, 交通手段の確保に重点を置くよう結論付けた。

\section{（4）行政が取り組む課題}

現在高梁市で行われている買い物弱者支援は高齢 者の外出支援としての公共交通の充実，すなわち市 中心部への移動手段の提供である。この支援状況は 交通弱者の移動を円滑にしているものの，同時に生 活インフラの市中心部への一極集中を促している.

生活に不便を感じているにも関わらず，転居を望 まない住人が多くいる一方で，現在の行政支援は生 活インフラの一極集中を促している. このような住 人のニーズへの対応として，小売店舗への資金援助 を提案する.

資金援助による小売店への効果として，(1)設備更 新の負担軽減による経営の健全化，(2)経営維持の見 通しが立ち，後継者不足や廃業を防ぐ，(3)品質管理 の高度化，(4)コストを消費者に転嫁する割合が減少 し，販売価格を下げられる，などが考光られる。

その結果郊外や山間部に打ける小売店の経営が維 持されれば，買い物弱者の買い物が確保される．買 い物弱者を克服した消費者による小売店の利用は, 小売店の顧客増加を意味する。このように，小売店 への資金援助をきっかけに，買い物弱者の解消之小 売店の経営維持の良循環が生まれる。

\section{4. 生協の個別宅配事業}

おかやまコープでは，カタログとマークシートを 


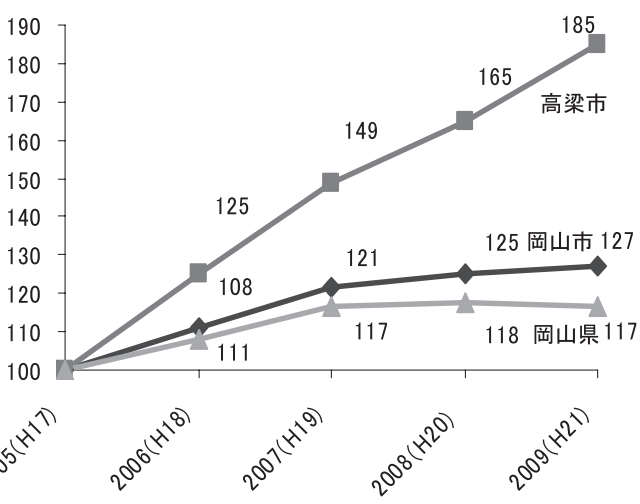

図 1. 岡山県, 高梁市, 岡山市の個別宅配売上の伸 び率

資料：ヒアリング調查より筆者作成

注）高梁市については, 平成 22 年 10 月時点の新見セン タ一の売上額と利用者数, および高梁市に住所を有 する利用者数より推計

用いた注文方式で，共同購入，個別宅配事業を行っ ている. 取扱商品は，食料品から日用品，CD など の娛楽品にいたるまで，スーパーマーケット以上に バラェティに富んでいる.

利用者は，「重いものを運ぶ必要が無くなった」, 「仕事で忙しくても買い物ができる」など，移動コ ストの削減を高く評価しているほか，安全面に配慮 した品質に注目する主婦層も多い。

2009（平成 21）年の個別宅配事業の売上額は, 岡山県で約 1.1 千万円，岡山市で約 450 万円，高梁 市で約 10 万円である。2005（平成 17）年度の売上 を 100 とした場合の伸び率を見ると，岡山県全体で は 127 に対し，高梁市では 185 と二倍近くまで伸び て拉り，今後の中山間地域に打注個別宅配事業の 発展が示唆されている.

\section{JA 広島市と Y ショップの提携事業}

A コープは，農村地区の住民にとっての食料調達 地点，すなわちライフラインともいえる位置づけで あった。しかし，JA 広島市の抱元る 14 店舗は農村 地区での人口流出, 高齢化で需要が低迷し, 店舗閉 鎖を余儀なくされている，JA広島市は，管内農家 の生活環境を維持しょうと店舗の経営維持に努めた が，A コープと同様に仕入先である問屋も減少しつ つあり，「仕入机弱者」となっていた。

そこで仕入先確保の方策として提案されたのが,
以前よりパンを仕入れていたヤマザキショップ（以

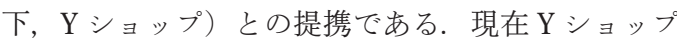
の業態を取っている店舗が 2 筒所，他にもヤマザキ の流通網を利用している店舗が 3 箇所ある. Y ショッ プの業態をとることは，(1)ヤマザキの全国物流網を 活かした商品供給体制を受けられる，(2)地域や立地 に合わせた品揃え，(3)ヤマザキならではの販売促進 企画がある，(4)売上に関係なく月々定額の運営費て 提携が可能，(5)加盟金，保証金，最低限運営にかか る固定費のみを支払い，ロイヤリティは無い，(6)運 営を自主性に任せて扣り，生産資材などJAならで はの品揃えが可能である，(7)管内産品を用いた商品 開発も可能である，これらの点でJA の目的に合致 していた．また，支所店舗がコンビニエンスストア 化することでオープンな䨌囲気ができ，従来店に入 りづらいと感じていた客層が気軽に来店できるよう になった。

店頭にはレトルト食品や文房具，雑誌など，通常 のコンビニエンスストアに似た品揃えに加えて，野 菜，魚，肉などの生鮮食品，生産資材など JA なら ではの商品まで並ぶ.

品揃兄以外飞も，顧客の利便性向上への配慮とし て，単身世帯から大家族までに対応した多様な量別 販売，注文に応じた無料の個別配達，口座引き落と しの掛売り，ポイントカード制度，月 2 回の特売開 催とチラシの配布などが行わ和る.

$\mathrm{Y} シ ョ ッ フ ゚$ 上水内店は，2009（平成 21）年 12 月 の開店以来，来客数，売上ともに上昇傾向にあるも のの，赤字を克服できてはいない，しかしながら， 担当職員は「管内農家の生活環境を維持する」とい ら存在意義を実感していた。

JA 広島市之同様に，買い物弱者を抱光る地域は 同時にその小売店舗が仕入れ弱者であることが考光 られる。コンビニエンスストアといら他業態との提 携は，流通網と販売ノウハウを活かすことで両者を 解決する糸口となるだろう。

JA 広島市も，赤字のまま経営を存続することは 困難である．店舗利用によって，管内住民が責任を 持ってその店舗を守る必要があることを，顧客に伝 える必要がある。また，JA広島市や管内住民の負 担軽減のために，適切な行政支援が行われることが 望ましい。 


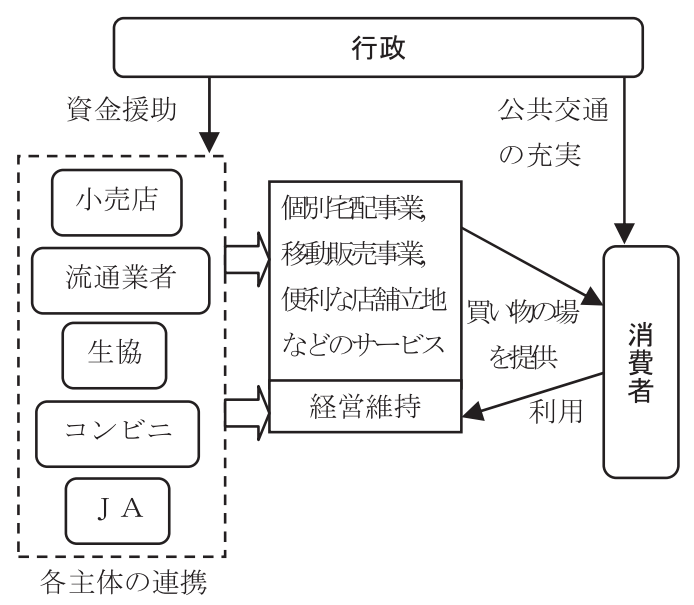

図 2. 買い物弱者の解消のプロセス

資料：筆者作

\section{6. 今後の対策についての提案}

第 2 節であげた買い物弱者支援システム（表 1) についてみると，高梁市の事例のような公共交通の 充実（3)移動手段の提供）は，中山間地域住民の生 活インフラ利用を可能にする。 しかし，移動コスト を伴ら生活はライフスタイルを大きく制限し，農村 での生産活動への悪影響を改善できるとは考えにく い. 農業と日常生活の両立には，生活の場に抢ける 生活インフラの充実が必要である.

これに対し，(1)宅配サービス，(2)移動販売，(4)便 利な店舗立地は, 初期投資や採算性の確保, 実現に 長期間を要するなどの課題があるものの，移動コス 卜削減の効果があり, 買い物弱者を根本的に解消寸 る手段として有効であると推察される。

よって，行政が小売店，個別配達業者など日用品
供給サイドへの資金援助を行い，より広域かつ多様 な地域の消費者の「買い物の場」を維持することを 提案する。これが(3)移動手段の提供と組久合わさっ て行われれば，消費者のライフスタイルの選択肢の 幅を広げることになると推察される。

\section{参考文献}

［1］国土交通省「人口減少・高齢化の進んだ集落 等を対象とした『日常生活に関するアンケー 卜調査』」2008 年.

［2］杉田 聡「買物難民一もらひとつの高齢者問 題」大月書店，2008 年.

[3] 杉江幸彦「みんなの話題『買物が不便……」 家の光（第八十六巻十一号） pp. 56-61，家の 光協会.

[4]本田 惊「過疎再生 コンビニ拠点に支援」, 日本農業新聞， 2010 年 8 月 18 日。

５５］日本農業新聞，2010 年 7 月 15 日。

６］日本経済新聞，2010 年 3 月 16 日.

[7] 高梁市備中町平川地区集落活性化計画協議会 「ひらかわ Do 拍子プロジェクト X」2008 年.

［8］玉川地域集落活性化計画策定協議会「玉川地 域（増原・下切）集落活性化計画書」2008 年.

[9] 小坂田稔「中山間地域に打汀る地域福祉型移 動販売開発方法の分析」2003 年.

[10］経済産業省「地域生活インフラを支える流通 のあり方研究会報告書」2010 年.

[11] 統計局「平成 17 年度国勢調査」 2007 年.

[12］高梁地域公共交通会議「高梁地域公共交通総 合連携計画」2010 年. 